\title{
Patterns of protein and carbohydrate accumulation during somatic embryogenesis of Acca sellowiana
}

\author{
Gabriela Claudia Cangahuala-Inocente ${ }^{(1)}$, Neusa Steiner $r^{(1)}$, Sara Beatriz Maldonado(2) \\ and Miguel Pedro Guerra ${ }^{(1)}$
}

\begin{abstract}
(1)Universidade Federal de Santa Catarina, Laboratório de Fisiologia do Desenvolvimento e Genética Vegetal, Programa de Pós-graduação em Recursos Genéticos Vegetais, Rodovia Admar Gonzaga, no 1346, Bairro Itacorubi, CEP 88034-001 Florianópolis, SC, Brazil. E-mail: gcangahu@hotmail.com, nsteiner@cca.ufsc.br, mpguerra@cca.ufsc.br (2)Universidad de Buenos Aires, Departamento de Biodiversidad y Biología Experimental, Laboratory 17. Pabellón 2, Ciudad Universitaria. C1428EHA. Ciudad de Buenos Aires, Argentina. E-mail: saram@bg.fcen.uba.ag
\end{abstract}

\begin{abstract}
The aim of this work was to quantify the protein, starch and total sugars levels during histodifferentiation and development of somatic embryos of Acca sellowiana Berg. For histological observations, the samples were dehydrated in a battery of ethanol, embedded in historesin and stained with toluidine blue (morphology), coomassie blue (protein bodies) and periodic acid-Schiff (starch). Proteins were extracted using a buffer solution, precipitated using ethanol and quantified using the Bradford reagent. Total sugars were extracted using a methanol-chloroform-water (12:5:3) solution and quantified by a reaction with anthrone at $0.2 \%$. Starch was extracted using a $30 \%$ perchloric acid solution and quantified by a reaction with anthrone at $0.2 \%$. During the somatic embryogenesis' in vitro morphogenesis and differentiation processes, the total protein levels decreased and the soluble sugars levels increased during the first 30 days in culture and remained stable until the $120^{\text {th }}$ day. On the other hand, total protein levels increased according to the progression in the developmental stages of the somatic embryos. The levels of total sugars and starch increased in the heart and cotyledonary stages, and decreased in the torpedo and pre-cotyledonary stages. These compounds play a central role in the development of somatic embryos of Acca sellowiana.
\end{abstract}

Index terms: total sugars, starch, pineapple guava, metabolism.

\section{Padrões de acúmulo de proteínas e carboidratos durante a embriogênese somática de Acca sellowiana}

Resumo - O objetivo deste trabalho foi quantificar os teores de proteína, amido e açúcares totais durante a histodiferenciação e desenvolvimento dos embriões somáticos em Acca sellowiana Berg. Para as observações histológicas, as amostras foram desidratadas em uma bateria de etanol, emblocadas em historesina e coradas com azul de toluidina (morfologia), azul de coomassie (corpos proteicos) e reativo ácido periódico de Schiff (amido). As proteínas foram extraídas usando uma solução tampão, precipitadas usando etanol e quantificadas por meio do reativo de Bradford. Os açúcares totais foram extraídos usando uma solução metanol-clorofórmioágua (12:5:3) e quantificados pela reação com antrona a $0,2 \%$. O amido foi extraído usando uma solução de ácido perclórico a $30 \%$ e quantificado pela reação com antrona a $0,2 \%$. Durante a diferenciação e morfogênese in vitro da embriogênese somática, os teores de proteínas totais decresceram e os açúcares solúveis aumentaram durante os 30 primeiros dias em cultura e permaneceram constantes até os 120 dias. Por outro lado, os teores das proteínas totais apresentaram incremento de acordo com a progressão nos estádios de desenvolvimento dos embriões somáticos. Os teores de açúcares totais e de amido aumentaram nos estádios cordiforme e cotiledonar e diminuíram nos estádios torpedo e pré-cotiledonar. Esses compostos exercem papel central no desenvolvimento de embriões somáticos de Acca sellowiana.

Termos para indexação: açúcares totais, amido, goiabeira serrana, metabolismo.

\section{Introduction}

There are evidences that the main metabolic and developmental processes occurring in the zygotic embryogenesis may be recapitulated in the somatic embryogenesis (Fehér et al., 2003). Some studies have focused on the association between synthesis and accumulation of starch and the development of somatic embryos. The results showed an increase in the starch levels in the late developmental stages, pointing out that starch is accumulated in higher levels in somatic embryos than in the zygotic ones (Merkle et al., 1995). These studies also suggest metabolic differences among zygotic and somatic embryos, the latter being less efficient in converting carbohydrates in lipids and storage proteins. 
The comprehension of biochemical processes is essential to elucidate the general mechanisms involved in somatic embryogenesis. However, the available information on cell metabolism and morphogenesis of embryogenetic systems is still limited (Nomura \& Komamine, 1995). The histodifferentiation of somatic embryos is normally associated with changes in the synthesis and mobilization of proteins, carbohydrates, and lipids. The levels of these substances change along the developmental stages of cell cultures, and their role has been ascribed to the transduction signal cascade or as substrate for cell growth and morphogenesis (Lulsdorf et al., 1992). Storage proteins are the source of amino acids for seed germination (Misra et al., 1993). Proteins could also be involved in the regulation of cell expansion and establishment of biophysical characteristics required for the morphogenesis (Jiménez, 2001). Soluble sugars, such as glucose and sucrose, are involved with the regulation of developmental processes occurring from embryo development to seed maturation (Gibson, 2005). Some of these studies showed an increase in the content of starch during the maturation of somatic embryos in concentrations higher than those normally found in the zygotic embryos, suggesting that the somatic embryos are metabolically distinct from zygotic ones and unable to efficiently convert carbohydrates into lipid and protein reserves (Merkle et al., 1995).

Somatic embryogenesis in pineapple guava [Acca sellowiana (O. Berg.) Burret] is morphologically well established (Canhoto \& Cruz, 1996; Dal Vesco \& Guerra, 2001; Guerra et al., 2001). Although the efficiency of embryo production has improved, pineapple guava somatic embryos still exhibit low rates of seedling conversion (Cangahuala-Inocente et al., 2007). Various storage reserves are present in somatic embryos, but their levels may not be sufficient to allow the complete conversion of heterotrophic embryos to photoautotrophic seedlings (Brownfield et al., 2007). Thus, it has been suggested that increasing somatic embryo storage compounds might result in an enhanced seedling production via improved conversion ratios (Brownfield et al., 2007).

In order to assist the development of efficient protocols, it is necessary to deepen on the biochemical and molecular basis of this morphogenetic route. Thus, the aim of this work was to quantify total proteins, total soluble sugars and starch accumulation during the induction, histodifferentiation and development of pineapple guava somatic embryos.

\section{Materials and Methods}

Zygotic embryos of Acca sellowiana were excised from mature seeds collected from fruits of the genotype 101 of Epagri's germplasm collection, located in São Joaquim, SC, Brazil. The seeds were soaked overnight in a mixture of water and $1.0 \% \mathrm{NaOCl}$, then rinsed three times in sterile water. In laminar-flow hood, the seeds had their embryos excised and then inoculated in test tubes $(22 \times 150 \mathrm{~mm})$ containing $10 \mathrm{~mL}$ of LPm culture medium (Von Arnold \& Eriksson, 1981), supplemented with Morel vitamins (Morel \& Wetmore, 1951); $8 \mathrm{mM}$ glutamine (Gln); $20 \mu \mathrm{M}$ 2,4-dichlorophenoxyacetic acid (2,4-D); $3 \%$ sucrose and $0.7 \%$ agar. The $\mathrm{pH}$ was adjusted to 5.8 prior to autoclaving at $121^{\circ} \mathrm{C}, 1 \mathrm{~atm}$, for $15 \mathrm{~min}$. The cultures were maintained in culture room in the dark, at $25^{\circ} \mathrm{C}$.

For biochemical assays, embryogenic cultures and somatic embryos at specific developmental stages were obtained at regular intervals (15 days) from 30 to 120 days in culture. The zygotic cotyledonary-staged embryos used as explants were considered time 0 . After 90 days in culture, somatic embryos were collected and classified according to the following developmental stages: heart, torpedo, pre-cotyledonary and cotyledonary. Five replicates of $200 \mathrm{mg}$ fresh weight (FW) each were collected and stored at $-20^{\circ} \mathrm{C}$ until the processing of the samples.

The samples were fixed for 24 hours in $0.2 \mathrm{M}$ phosphate buffer ( $\mathrm{pH}$ 7.3) containing $2.5 \%$ paraformaldehyde, dehydrated in graded ethanol series, and embedded in historesin (Leica) as described by Cangahuala-Inocente et al. (2004). Thick sections with $5 \mu \mathrm{m}$ were cut using a rotary microtome (Slee Technik) and fixed onto slides. Samples were dehydrated using periodic acid and stained by periodic acid-Schiff reaction (PAS) to reveal starch grains. Storage proteins were stained using coomassie brilliant blue R250 (CBB) (Gahan, 1984), and acid polysaccharides and phenols were stained using $0.5 \%$ toluidine blue O (TBO) (O'Brien et al., 1964). Photographs were taken using a standard Olympus BX 40 microscope and Olympus SZH10 stereomicroscope. 
The samples were macerated at $4^{\circ} \mathrm{C}$ using extraction buffer ( $\mathrm{pH} 7.0$ ) containing $50 \mathrm{mM}$ sodium phosphate dibasic, $0.2 \mathrm{M} \beta$-mercaptoethanol, $17.3 \mathrm{mM}$ sodium dodecyl sulphate(SDS), and $1 \mathrm{mM}$ phenylmethylsulfonyl fluoride, and then centrifuged for $20 \mathrm{~min}$ at $8,000 \mathrm{rpm}$ at $0^{\circ} \mathrm{C}$. Total proteins were precipitated using absolute ethylic alcohol and centrifuged at 10,000 rpm during $20 \mathrm{~min}$ at $0^{\circ} \mathrm{C}$. The protein levels were determined (Bradford, 1976) using coomassie brilliant blue R250 (Sigma). The absorbance was read using a UV-Vis UV-1203 Shimadzu spectrophotometer at $595 \mathrm{~nm}$. The determination of total proteins was performed using bovine serum albumin as standard.

The extraction of total soluble sugars was performed according to Shannon (1968). The pellet from the protein extraction was macerated using $2 \mathrm{~mL}$ methanol:chloroform:water (MCW) (12:5:3), centrifuged for $10 \mathrm{~min}$ at 2,000 $\mathrm{rpm}$. The supernatant was recovered and the pellet was re-extracted using $2 \mathrm{~mL} \mathrm{MCW}$. One part chloroform and 1.5 part water were added for each four parts of the supernatant, followed by centrifuging for $10 \mathrm{~min}$ at $2,000 \mathrm{rpm}$, from which two phases were obtained. The upper aqueous phase was removed for dosage using anthrone at $0.2 \%$, in accordance with Umbreit et al. (1964). The absorbance was read in UV-VIS UV-1203 spectrophotometer (Shimadzu) at $620 \mathrm{~nm}$.

The extraction and determination of starch levels were based on the procedures of McCready et al. (1950). The pellets were ground with $1 \mathrm{~mL}$ of $30 \%$ perchloric acid and centrifuged for $15 \mathrm{~min}$ at $10,000 \mathrm{rpm}$. The supernatant containing starch was removed and the pellets were re-extracted twofold. The supernatants were combined and the pellets eliminated. The sugar and starch concentrations were calculated using glucose as standard.

The data were submitted to (ANOVA) and presented as means of five replicates. Student-Newman-Keuls mean separation test was used to indicate significant differences $(p<0.05)$ using Statistic version 7.0 software.

\section{Results and Discussion}

Somatic embryos arose from the cotyledonary surface of explants (Figure 1 A), and the highest embryogenic induction rate $(100 \%)$ as well as the greatest production of somatic embryos per explant (113) were observed in LPm medium supplemented with glutamin and 2,4-D
(Figure $1 \mathrm{~A}$ ) after 90 days in culture, thus confirming the results of Cangahuala-Inocente et al. (2007). At this time, a large number of somatic embryos was observed in the globular (Figure $1 \mathrm{~B}$ ), heart (showing cotyledon initials, Figure $1 \mathrm{C}$ ), torpedo (Figure $1 \mathrm{D}$ ), pre-cotyledonary (Figure $1 \mathrm{E}$ ), and cotyledonary (Figure 1 F) stages. Similar stages were observed in

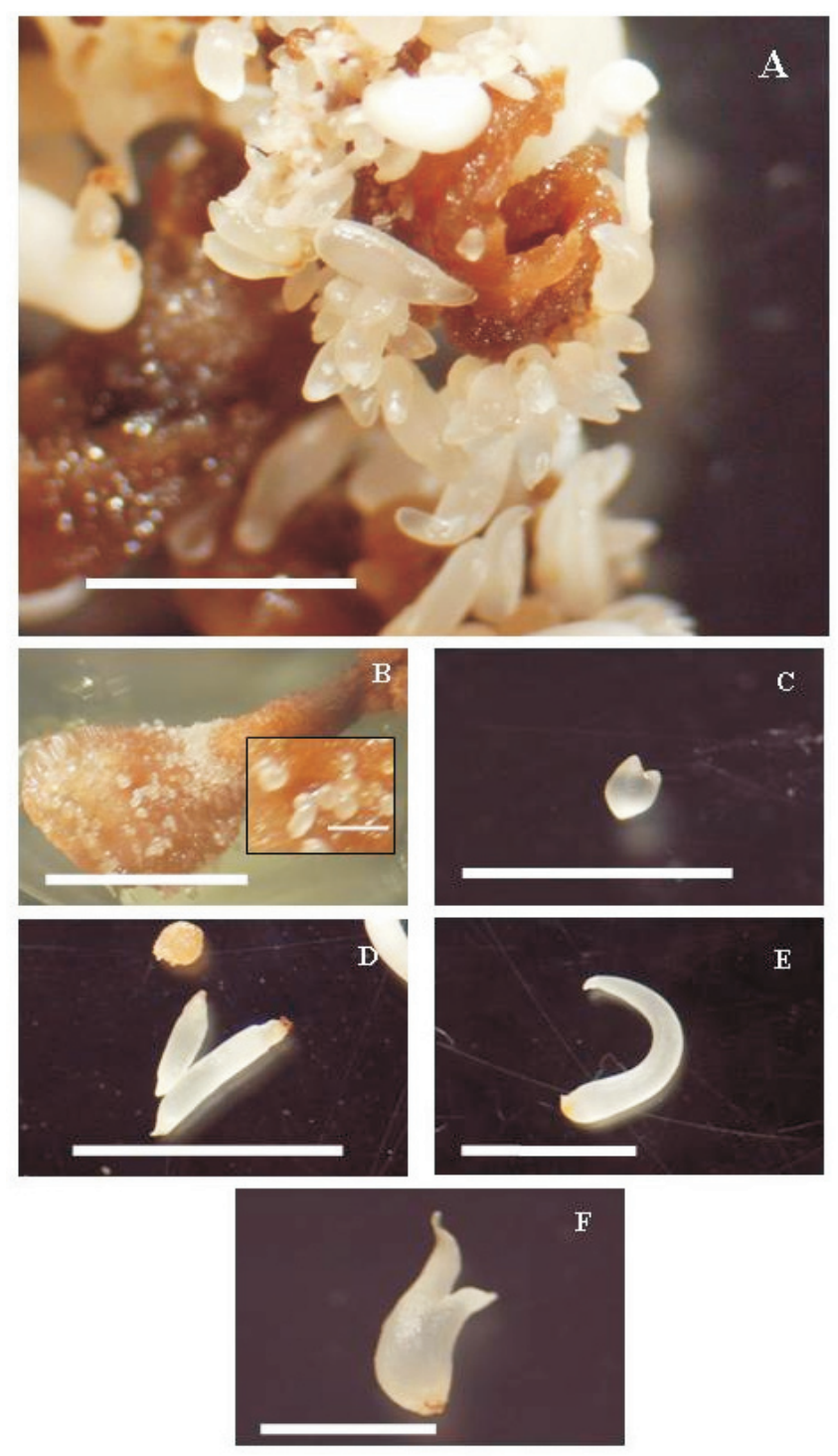

Figure 1. A, somatic embryo of $A$. sellowiana in different developmental stages; B, globular-staged somatic embryos (see detail); C, heart-staged somatic embryos; D, torpedostaged somatic embryos; E, pre-cotyledonary-staged somatic embryos; F, cotyledonary-staged somatic embryos. Bar: A, C, D and F, $1 \mathrm{~cm}$; B, $0.5 \mathrm{~cm}$. Photos by G.C. CangahualaInocente. 
Opuntia ficus-indica (Gomes et al., 2006), and Psidium guajava (Rai et al., 2007).

Histological sections revealed the main features of each stage (Figure 2). Thus, globular-staged somatic embryos showed small protein bodies (Figure $2 \mathrm{~A}$ ), spherical cells with dense cytoplasm rounded by the protoderm (Figure 2 B) and starch granules (Figure $2 \mathrm{C}$ ). Heart-staged somatic embryos showed protein bodies in the whole cell, especially in the embryonal axis (Figure $2 \mathrm{D}$ ). Torpedo-staged somatic embryos showed a conspicuous protoderm and a welldefined apex besides root regions nearly connected by procambial strands (Figure 2 E). Pre-cotyledonary somatic embryos were elongated with well defined cotyledonary leaves. Their cells were different from those present in the embryonal axis (Figure $2 \mathrm{~F}$ ). Cotyledonary-staged somatic embryos showed expanded cotyledonary leaves (Figure 1 F). Similar morphogenetic features have been described for cork oak by Puigderrajols et al. (2001). Histological sections of Opuntia ficus-indica showed a well formed globular embryo with a conspicuous protoderm. The initiation of a vascular system was seen only at the distal end of a torpedo-shaped embryo, and cotyledonary-staged somatic embryos showed a closed vascular system, tracheary vessels, bifurcating procambium strands, differentiating shoot apical meristem region, root pole, and cotyledon initials (Gomes et al., 2006).

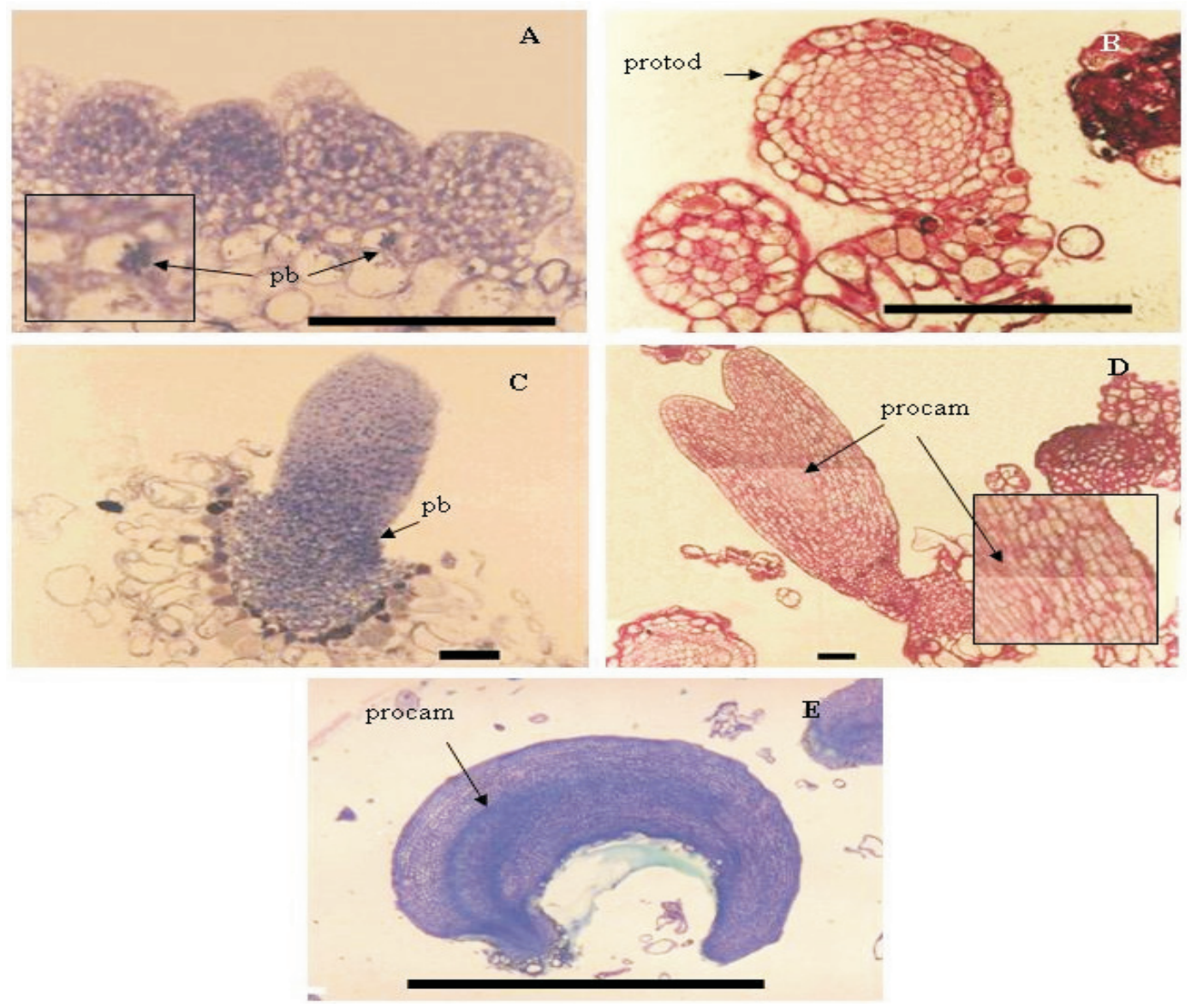

Figure 2. Histological sections of different stages of development of the somatic embryogenesis of A. sellowiana. A, globular-staged somatic embryos with protein bodies stained by CBB (see detail); B, stained by TBO; C, stained by PAS; C, heart-staged somatic embryos stained by CBB; $\mathrm{D}$, torpedo-staged somatic embryos stained by PAS (see detail); E, pre-cotyledonary-staged somatic embryos stained by TBO. pb, protein bodies; protod, protoderm; procam, procambium. Bar: A, B and C, $200 \mu \mathrm{m}$; D, $100 \mu \mathrm{m} ; \mathrm{E}, 1 \mathrm{~cm}$. Photos by G.C. Cangahuala-Inocente. 
Low levels of total proteins were observed during the entire experimental period (Figure $3 \mathrm{~A}$ ). These values were lower than those observed in the zygotic embryos used as explants at the time of inoculation (1.1 $\left.\mathrm{mg} \mathrm{g}^{-1} \mathrm{FW}\right)$. After 105 and 120 days, the embryogenic cultures showed low levels of total proteins (Figure $3 \mathrm{~A}$ ). A decrease of proteins levels in the tissues of explant and resulting pro-embryonary cultures was also observed during the induction phase of somatic embryogenesis. In Saccharum sp. it was observed that arginine enhanced total soluble proteins in embryogenic cultures during embryo differentiationmaturation (Nieves et al., 2008).

Embryogenic induction and development are commonly associated with a consumption of proteins present in the explant tissues for the re-differentiation of somatic cells. Embryogenic competent cells are originated from explant tissues in response to specific inductive treatments, e.g. after treatment with 2,4-D (Fehér, 2006), as observed in the present work. The high
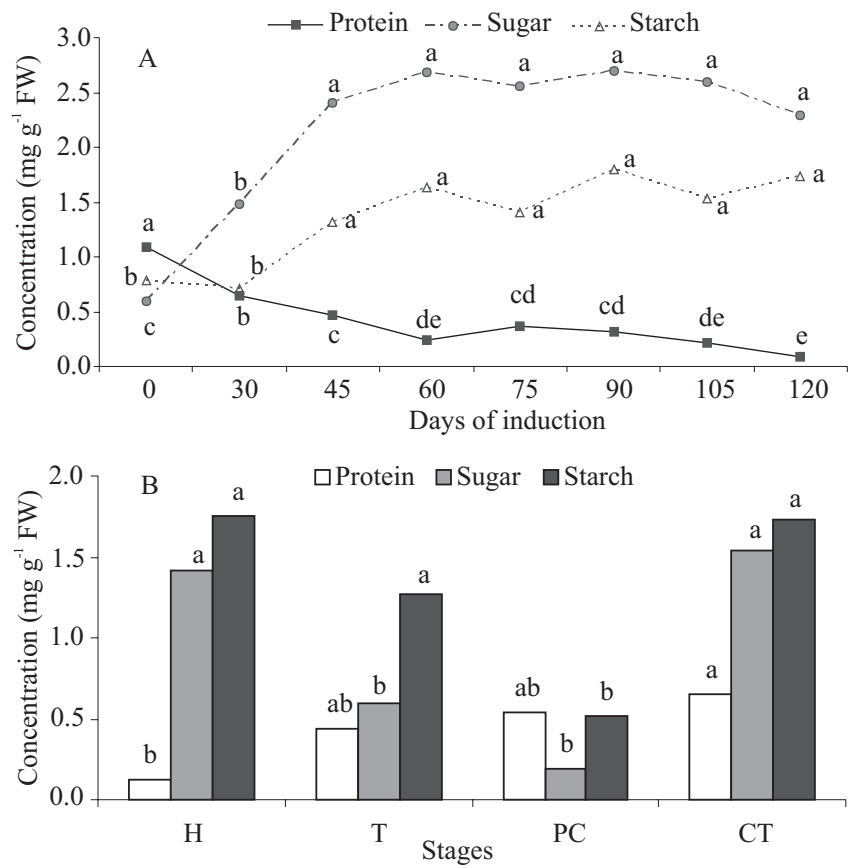

Figure 3. Levels of total proteins, soluble sugars and starch ( $\mathrm{mg} \mathrm{g}^{-1}$ fresh weight $-\mathrm{FW}$ ) of $A$. sellowiana during differentiation of somatic embryogenesis (A), and in different developmental stages of somatic embryos (B). Mean of five replicates. H, heart; T, torpedo; PC, pre-cotyledonary; CT, cotyledonary. Values followed by different letters inside parameters indicate significant differences according to the SNK test $(\mathrm{p}<0.05)$. $\mathrm{CV}$ (proteins) $=$ $29.4 \% ; \mathrm{CV}($ sugar $)=6.8 \% ; \mathrm{CV}($ starch $)=40.7 \%$. protein levels observed in the zygotic embryos used as explants at the inoculation time may be considered a criterion for the induction of somatic embryogenesis as suggested by Jiménez (2001).

The total proteins levels of somatic embryos increased according to the progression in the developmental stages (Figure 3 B), confirming the same pattern of behavior for the accumulation of proteins in this same species (Cangahuala-Inocente et al., 2009). The protein levels ranged from $0.1 \mathrm{mg} \mathrm{g}^{-1} \mathrm{FW}$ in the heart stage to $0.7 \mathrm{mg} \mathrm{g}^{-1} \mathrm{FW}$ in the cotyledonary stage. These values were lower than those observed in mature zygotic embryos (Table 1), and the same was observed in Phoenix dactylifera (Sané et al., 2006) and Pisum sativum (Griga et al., 2007).

As observed in histological sections, the protein bodies were synthesized in early developmental stages and stored in the cotyledonary leaves of mature somatic embryos. Thus, the levels of total protein in somatic embryos increased during the progression of developmental stages, and this could be ascribed to the synthesis of storage proteins, among them Late Embryogenesis Abundant (LEA) proteins, as well as of those showing high affinity with water molecules and acting in seed dehydration and protection (Wise $\&$ Tunnacliffe, 2004). However, the values observed in cotyledonary-staged somatic embryos were lower than those observed in cotyledonary-staged zygotic embryos. Contrarily, loblolly pine somatic embryos showed enhanced levels of storage proteins as compared to zygotic embryos (Brownfield et al., 2007). In Eucalyptus nitens, somatic embryos showed slightly lower levels of storage proteins in their cotyledonary cells as compared to zygotic embryos (Bandyopadhyay \& Hamill, 2000).

Differential content of starch and reducing sugars were reported as metabolic markers in embryogenic and non-embryogenic calluses of Medicago arborea. High

Table 1. Levels of protein, soluble sugars, and starch ( $\mathrm{mg} \mathrm{g}^{-1}$ fresh weight - FW) of $A$. sellowiana cotyledonary-staged somatic and zygotic embryos. Mean of five replicates ${ }^{(1)}$.

\begin{tabular}{lccc}
\hline $\begin{array}{l}\text { Cotyledonary-staged } \\
\text { embryos }\end{array}$ & $\begin{array}{c}\text { Total protein } \\
\left(\mathrm{mg} \mathrm{g}^{-1} \mathrm{FW}\right)\end{array}$ & $\begin{array}{c}\text { Soluble sugars } \\
\left(\mathrm{mg} \mathrm{g}^{-1} \mathrm{FW}\right)\end{array}$ & $\begin{array}{c}\text { Starch } \\
\left(\mathrm{mg} \mathrm{g}^{-1} \mathrm{FW}\right)\end{array}$ \\
\hline Somatic & $0.7 \mathrm{~b}$ & $1.5 \mathrm{a}$ & $1.7 \mathrm{a}$ \\
Zygotic & $1.1 \mathrm{a}$ & $0.6 \mathrm{~b}$ & $0.8 \mathrm{~b}$ \\
\hline CV $(\%)$ & 23.4 & 8.2 & 16.9 \\
\hline
\end{tabular}

${ }^{(1)}$ Values followed by different letters inside parameters indicate significant differences according to the SNK test $(\mathrm{p}<0.05)$. 
levels of sugars and low levels of starch were found in embryogenic cultures in contrast to non-embryogenic ones (Martin et al., 2000). In the present work, the highest levels of total soluble sugars were observed from 45 to 120 days in culture (Figure 3 A). However, the observed values in the whole time in culture were higher than those observed in the zygotic embryo in inoculation time $\left(0.6 \mathrm{mg} \mathrm{g}^{-1}\right.$ soluble sugars, and $0.8 \mathrm{mg} \mathrm{g}^{-1}$ starch). It is suggested that the availability of carbohydrates present in the culture medium could increase the internal levels of soluble sugars. Previous studies showed that when the hexoses were favored, cell division and differentiation were promoted; when sucrose was the predominant sugar, processes such as cell elongation as well storage of proteins and carbohydrates were stimulated (Borisjuk et al., 2004).

High starch levels were observed during the expression of somatic embryogenesis, observed from the $45^{\text {th }}$ day in culture to the final evaluation. This time lapse coincides with the formation and greatest production of somatic embryos in these same species, as reported by Cangahuala-Inocente et al. (2007). Somatic embryogenesis is a morphogenetic process that requires a high amount of energy, and accordingly the starch catabolism results in intermediary glycolic compounds that provide the necessary ATP to the cell metabolism as postulated by Martin et al. (2000).

Total soluble sugars in somatic embryos ranged according to the developmental stages (Figure $3 \mathrm{~B}$ ). The highest values (1.4 and $1.5 \mathrm{mg} \mathrm{g}^{-1} \mathrm{FW}$ ) were observed in heart and cotyledonary-staged somatic embryos, respectively. In these stages the somatic embryos also revealed the highest values for $\operatorname{starch}\left(1.8\right.$ and $1.7 \mathrm{mg} \mathrm{g}^{-1}$ $\mathrm{FW}$, respectively). These values were higher than those observed in cotyledonary-staged zygotic embryos (Table 1), thus suggesting the role of these compounds in the normal histogenesis and histodifferentiation of somatic embryos. In this same species, the hexoses/sucrose ratio influenced cell division and differentiation in early developmental stages of zygotic and somatic embryo, while starch was involved in carbohydrate partitioning and storage (Pescador et al., 2008).

Moreover, the low levels of total proteins and the high levels of starch and total soluble sugars present in cotyledonary-staged somatic embryos, when compared with the values observed in the zygotic embryos of $A$. sellowiana (Table 1), could negatively affect the conversion rate of somatic embryos and the synthesis and storage of protein bodies, as suggested by Cangahuala-Inocente et al. (2004). In this same species, starch levels increased continuously in zygotic embryos and decreased in somatic ones. Starch accumulation was significantly higher in torpedo and cotyledonary-staged somatic embryos than in the corresponding zygotic ones (Pescador et al., 2008). In conifer somatic embryos, conifers carbohydrates play an essential role and the failure to reach the adequate levels results in their poor development (Lipavská \& Konrádová, 2004).

Alternatively, the levels of nitrogenous compounds present in the culture medium were not sufficient for the metabolism of amino acids products. This could impair the synthesis of storage products and negatively affect the conversion of somatic embryos to plantlets in this species, as showed previously (Cangahuala-Inocente et al., 2007). In Elaeis guineensis, the reduced vigor of plantlets was attributed to the low levels of storage proteins present in the somatic embryos (Morcillo et al., 1999).

\section{Conclusions}

1. The levels of total proteins decrease and the soluble sugars levels increase during the first 30 days in culture, then remain stable until the $120^{\text {th }}$ day during the developmental process of somatic embryogenesis of Acca sellowiana.

2. The total protein levels increase according to the progression in the developmental stages of somatic embryos.

3. The levels of soluble sugars and starch increase in heart and cotyledonary-staged somatic embryos, and decrease in torpedo and precotyledonary-staged somatic embryos.

4. The carbon source supplemented to the culture medium affects the accumulation of total sugars and starch during the different developmental stages of somatic embryos.

\section{Acknowledgements}

To Coordenação de Aperfeiçoamento de Pessoal de Nível Superior, Conselho Nacional de Desenvolvimento Científico e Tecnológico, and Fundação de Apoio à Pesquisa Científica e Tecnológica do Estado de Santa Catarina for the support. 


\section{References}

BANDYOPADHYAY, S.; HAMILL, J.D. Ultrastructural studies of somatic embryos of Eucalyptus nitens and comparisons with zygotic embryos found in mature seeds. Annals of Botany, v.86, p.237-244, 2000.

BORISJUK, L.; ROLLETSCHEK, H.; RADCHUK, R.; WESCHKE, W.; WOBUS, U.; WEBER, H. Seed development and differentiation: a role for metabolic regulation. Plant Biology, v.6, p.375-386, 2004.

BRADFORD, M.M. A rapid and sensitive method for the quantification of microgram quantities of protein utilizing the principle of protein-dye binding. Analytical Biochemistry, v.72, p.248-254, 1976.

BROWNFIELD, D.L.; TODD, C.D.; STONE, S.L.; DEYHOLOS, M.K.; GIFFORD, D.J. Patterns of storage protein and triacylglycerol accumulation during loblolly pine somatic embryo maturation. Plant Cell Tissue and Organ Culture, v.88, p.217-223, 2007.

CANGAHUALA-INOCENTE, G.C.; DAL VESCO, L.L.; STEINMACHER, D.; TORRES, A.C.; GUERRA, M.P. Improvements in somatic embryogenesis protocol in Feijoa (Acca sellowiana (Berg) Burret): induction, conversion and synthetic seeds. Scientia Horticulturae, v.111, p.228-234, 2007.

CANGAHUALA-INOCENTE, G.C.; STEINER, N.; SANTOS, M.; GUERRA, M.P. Morphohistological analysis and histochemistry of Feijoa sellowiana somatic embryogenesis. Protoplasma, v.224, p.33-40, 2004.

CANGAHUALA-INOCENTE, G.C.; VILLARINO, A.; SEIXA, D.; DUMAS-GAUDOT, E.; TERENZI, H.; GUERRA, M.P. Differential proteomic analysis of developmental stages of Acca sellowiana somatic embryos. Acta Physiologiae Plantarum, v.33, p.45-53, 2009.

CANHOTO, J.M.; CRUZ, G.S. Feijoa sellowiana Berg (Pineapple guava). In: BAJAJ, Y.P.S. (Ed.). Trees IV. Berlin: Springer Verlag, 1996. p.156-172. (Biotechnology in Agriculture and Forestry, 35).

DAL VESCO, L.L.; GUERRA, M.P. The effectiveness of nitrogen sources in Acca (Feijoa sellowiana Berg) somatic embryogenesis. Plant Cell, Tissue and Organ Culture, v.64, p.19-25, 2001.

FEHÉR, A. Why somatic plant cells start to form embryos? In: MUJIB, A.; ŠAMAJ, J. (Ed.). Somatic embryogenesis. Berlin: Springer, 2006. 357p. (Plant Cell Monographs, 2).

FEHÉR, A.; PASTERNAK, T.P.; DUDITS, D. Transition of somatic plant cells to an embryogenic state. Plant Cell, Tissue and Organ Culture, v.74, p.201-228, 2003.

GAHAN, P.B. Plant histochemistry and cytochemistry: an introduction. London: Academic Press, 1984. 301p.

GIBSON, S.I. Control of plant development and gene expression by sugar signaling. Current Opinion in Plant Biology, v.8, p.93-102, 2005.

GOMES, F.L.A.F.; HEREDIA, F.F.; SILVA, P.B. e; FACO, O.; CAMPOS, F.A.P. Somatic embryogenesis and plant regeneration in Opuntiaficus-indica (L.) Mill.(Cactaceae). Scientia Horticulturae, v.108, p.15-21, 2006.
GRIGA, M.; HORÁČEK, J.; KLENOTIČOVÁ, H. Protein patterns associated with Pisum sativum somatic embryogenesis. Biologia Plantarum, v.51, p.201-211, 2007.

GUERRA, M.P.; DAL VESCO, L.L.; DUCROQUET, J.P.H.J.; NODARI, R.O.; REIS, M.S. dos. Somatic embryogenesis in goiabeira serrana: genotype response, auxinic shock and synthetic seeds. Revista Brasileira de Fisiologia Vegetal, v.13, p.117-128, 2001

JIMÉNEZ, V.M. Regulation of in vitro somatic embryogenesis with emphasis on the role of endogenous hormones. Revista Brasileira de Fisiologia Vegetal, v.13, p.196-223, 2001.

LIPAVSKÁ, H.; KONRÁdOVÁ, H. Somatic embryogenesis in conifers: the role of carbohydrate metabolism. In Vitro Cellular and Development Biology Plant, v.40, p.23-30, 2004.

LULSDORF, M.M.; TAUTORUS, T.E.; KIKCIO, S.I.; DUNSTAN, D.I. Growth parameters of embryogenic suspension culture of interior spruce (Picea glauca-engelmannii complex) and black spruce (Picea mariana Mill.). Plant Science, v.82, p.227-234, 1992.

MARTIN, A.B.; CUADRADO, Y.; GUERRA, H.; GALLEGO, P.; HITA, O.; MARTIN, L.; DORADO, A.; VILLALOBOS, N. Differences in the contents of total sugars, reducing sugars, starch and sucrose in embryogenic and non-embryogenic calli from Medicago arborea L. Plant Science, v.154, p.143-151, 2000 .

MCCREADY, R.M.; GUGGOLZ, J.; OWENS, H.S. Determination of starch and amylose in vegetables. Analytical Chemistry, v.22, p.1156-1158, 1950.

MERKLE, S.A.; PARROTT, W.A.; FLINN, B.S. Morphogenic aspects of somatic embryogenesis. In: THORPE, T.A. (Ed.). In vitro embryogenesis in plants. Dordrecht: Kluwer Academic, 1995. p.155-203.

MISRA, S.; ATTREE, S.M.; LEAL, I.; FOWKE, L.C. Effect of abscisic acid, osmoticum, and desiccation on synthesis of storage proteins during the development of white spruce somatic embryos. Annals of Botany, v.71, p.11-22, 1993.

MORCILLO, F.; ABERLENC-BERTOSSI, F.; NOIROT, M.; HAMON, S.; DUVAL, Y. Differential effect of glutamine and arginine on $7 \mathrm{~S}$ globulin accumulation during the maturation of oil palm somatic embryos. Plant Cell Reports, v.18, p.868-872, 1999.

MOREL, G.M.; WETMORE, R.H. Tissue culture of monocotyledons. American Journal of Botany, v.38, p.138-140, 1951.

NIEVES, N.; SAGARRA, F.; GONZÁLEZ, R.; LEZCANO, Y.; CID, M.; BLANCO, M.A.; CASTILLO, R. Effect of exogenous arginine on sugarcane (Saccharum sp.) somatic embryogenesis, free polyamines and the contents of the soluble proteins and praline. Plant Cell, Tissue and Organ Culture, v.95, p.313-320, 2008.

NOMURA, K.; KOMAMINE, A. Physiological and biochemical aspects of somatic embryogenesis. In: THORPE, T.A. (Ed.). In vitro embryogenesis in plants. Dordrecht: Kluwer Academic, 1995. p.249-266. 
O'BRIEN, T.P.; FEDER, N.; MCCULLY, M.E. Polychromatic staining of plant cell walls by toluidine blue O. Protoplasma, v.59, p.368-373, 1964.

PESCADOR, R.; KERBAUY, G.B.; KRAUS, J.E.; FERREIRA, W. de M.; GUERRA, M.P.; FIGUEIREDO-RIBEIRO, R. de C. Changes in soluble carbohydrates and starch amounts during somatic and zygotic embryogenesis of Acca sellowiana (Myrtaceae). In Vitro Cellular and Developmental Biology-Plant, v.44, p.289-299, 2008.

PUIGDERRAJOLS, P.; MIR, G.; MOLINAS, M. Ultrastructure of early embryogenesis by multicellular and unicellular pathways in cork oak (Quercus suber L.). Annals of Botany, v.87, p.179-189, 2001.

RAI, M.K.; AKHTAR, N.; JAISWAL, V.S. Somatic embryogenesis and plant regeneration in Psidium guajava L. cv. Banarasi local. Scientia Horticulturae, v.113, p.129-133, 2007.
SANÉ, D.; ABERLENC-BERTOSSI, F.; GASSAMA-DIA, Y.K.; SAGNA, M.; TROUSLOT, M.F.; DUVAL, Y.; BORGEL, A. Histocytological analysis of callogenesis and somatic embryogenesis from cell suspensions of date palm (Phoenix dactylifera). Annals of Botany, v.98, p.301-308, 2006.

SHANNON, J.C. A procedure for the extraction and fractionation of carbohydrates from immature Zea mays kernels. Research Bulletin, v.842, p.1-8, 1968.

UMBREIT, W.W.; BURRIS, R.H.; STAUFFER, J.F. Manometric techniques. Minneapolis: Burgess, 1964.

VON ARNOLD, S.; ERIKSSON, T. In vitro studies of adventitious shoot formation in Pinus contorta. Canadian Journal of Botany, v.59, p.870-874, 1981.

WISE, M.J.; TUNNACLIFFE, A. POPP the question: what do LEA proteins do? Trends in Plant Science, v.9, p.13-17, 2004.

Received on November 5, 2008 and accepted on February 27, 2009 